\title{
Bioactive Compounds of Tomato Fruit in Response to Salinity, Heat and Their Combination
}

\author{
María Ángeles Botella ${ }^{1}$ D, Virginia Hernández ${ }^{2}$, Teresa Mestre ${ }^{3}$ (D) Pilar Hellín 2,4, \\ Manuel Francisco García-Legaz ${ }^{5}$, Rosa María Rivero ${ }^{3,4}{ }^{(D)}$, Vicente Martínez ${ }^{3,4}$, José Fenoll 2,4 (D) \\ and Pilar Flores $2,4, *$
}

1 Departamento de Biología Aplicada, EPSO, Universidad Miguel Hernández, Orihuela, 03312 Alicante, Spain; mangeles.botella@umh.es

2 Instituto Murciano de Investigación y Desarrollo Agrario (IMIDA), Santo Ángel, 30151 Murcia, Spain; virginia.hernandez5@carm.es (V.H.); mariap.hellin@carm.es (P.H.); jose.fenoll@carm.es (J.F.)

3 Centro de Edafología y Biología Aplicada del Segura, CSIC, 30100 Murcia, Spain; tmestre@cebas.csic.es (T.M.); rmrivero@cebas.csic.es (R.M.R.); vicente@cebas.csic.es (V.M.)

4 Unidad Asociada Grupo de Fertirriego y Calidad Hortofrutícola (IMIDA-CSIC), 30150 Murcia, Spain

5 Departamento de Agroquímica y Medio Ambiente, EPSO, Universidad Miguel Hernández, Orihuela, 03312 Alicante, Spain; F.Garcia-Legaz@umh.es

* Correspondence: mpilar.flores@carm.es

Citation: Botella, M.Á.; Hernández, V.; Mestre, T.; Hellín, P.; García-Legaz, M.F.; Rivero, R.M.; Martínez, V.; Fenoll, J.; Flores, P. Bioactive Compounds of Tomato Fruit in Response to Salinity, Heat and Their Combination. Agriculture 2021, 11, 534. https://doi.org/10.3390/ agriculture11060534

Academic Editor: Alessandra Durazzo and Isabel Lara Ayala

Received: 22 April 2021

Accepted: 7 June 2021

Published: 10 June 2021

Publisher's Note: MDPI stays neutral with regard to jurisdictional claims in published maps and institutional affiliations.

Copyright: (c) 2021 by the authors. Licensee MDPI, Basel, Switzerland. This article is an open access article distributed under the terms and conditions of the Creative Commons Attribution (CC BY) license (https:// creativecommons.org/licenses/by/ $4.0 /)$.

\begin{abstract}
In light of foreseen global climatic changes, we can expect crops to be subjected to several stresses that may occur at the same time, but information concerning the effect of long-term exposure to a combination of stresses on fruit yield and quality is scarce. This work looks at the effect of a long-term combination of salinity and high temperature stresses on tomato yield and fruit quality. Salinity decreased yield but had positive effects on fruit quality, increasing TSS, acidity, glucose, fructose and flavonols. High temperatures increased the vitamin $C$ content but significantly decreased the concentration of some phenolic compounds (hydroxycinnamic acids and flavanones) and some carotenoids (phytoene, phytofluene and violaxanthin). An idiosyncrasy was observed in the effect of a combination of stresses on the content of homovanillic acid $O$-hexoside, lycopene and lutein, being different than the effect of salinity or high temperature when applied separately. The effect of a combination of stresses may differ from the effects of a single stress, underlining the importance of studying how stress interactions may affect the yield and quality of crops. The results show the viability of exploiting abiotic stresses and their combination to obtain tomatoes with increased levels of health-promoting compounds.
\end{abstract}

Keywords: sugars; carotenoids; phenolic; antioxidants; nutritional quality; high temperature; $\mathrm{NaCl}$

\section{Introduction}

Tomato (Solanum lycopersicum L.) is an important horticultural crop worldwide and one of the most consumed vegetables in the world. Several abiotic stresses, such as water deficit, salinity and extreme temperatures, can affect crop production. The effects of one of these single stresses on plant production and physiological, biochemical and molecular changes have been widely studied in the literature. In particular, tomato plants are often cultivated in arid or semi-arid regions of the world, where salinity and high temperature threaten to become, or already are, a problem. The effect of irrigation with saline waters on tomato fruit has been well documented, indicating a decrease in yield and changes in fruit quality [1], usually leading to better tasting fruits [2,3]. In relation to high temperatures, several studies have shown a decrease in tomato fruit yield [4,5], and some authors have indicated that secondary metabolites were more affected than primary metabolites [6]. Moreover, different responses to heat conditions amongst tomato genotypes have been associated with the different effects of heat on some photosynthetic parameters [7]. 
Agricultural land in arid or semi-arid regions can be affected not only by a single stress, but by several stress conditions simultaneously. Moreover, considering the predicted global climatic changes, we can expect this situation to be exacerbated, with serious consequences [8]. Recently, several studies have focused on the effect of combinations of various stresses on plant physiological responses $[9,10]$. Some results have indicated that when plants are subjected to a combination of abiotic stresses, the response may be different from that under each stress applied separately [10].

Similarly, results have indicated that the combination of various stresses had a greater impact on plant growth and productivity than a single stress [8,11]. Nevertheless, some reports have shown that a combination of stresses (e.g., salinity and heat) may lead to better plant behavior than when each stress was applied individually $[9,12,13]$. However, it is important to note that most of these studies reported on the short-term physiological effects of stress combinations, while information about the effect of long-term exposure to a combination of stresses on fruit yield and quality is scarce.

The aspects of productivity and sensory quality have attracted most attention, but recently, there has been increasing interest in the nutritional value of fruits and vegetables [14], as consumers demand products with a high content of health-promoting constituents. In this respect, tomato is an important source of carotenoids such as $\beta$-carotene, a precursor of vitamin A; lycopene, which has been associate to a reduction in the risk of cancer, cardiovascular disease and macular degeneration [15]; lutein, which plays a fundamental role in the protection of vision [16] and in preventing age-related maculopathy [17]; others that have been less well studied, such as phytoene and phytofluene, which may contribute to inhibiting the progression of atherosclerosis [18]. Furthermore, tomato is also a source of phenolic compounds such as flavonoids and hydroxycinnamic acid derivatives and vitamins such as ascorbic acid. All of these compounds contribute to its antioxidant properties and beneficial health effects [19].

The above-mentioned compounds are important for the commercial quality of tomato and can be affected by factors such as variety and environmental, agricultural and postharvest conditions [20]. Moreover, using controlled abiotic stress may be an interesting approach to improve the nutraceutical value of fruits and vegetables [21]. Taking all of this into consideration, the aim of this work was to study the effect of a combination of different stresses (salinity and high temperature) on tomato yield and fruit quality. Unlike most previous studies found in the literature, this study involves the long-term exposure to the combination of stresses, according to the current growing conditions, and allows for elucidating the effect of these stresses on the final bioactive composition of the fruit.

\section{Materials and Methods}

The study was carried out from April (mid-spring) to July (mid-summer) in two polycarbonate greenhouses. Tomato seedlings (Solanum lycopersicum L.) were transplanted to $120 \mathrm{~L}$ containers (1 plant per container) with aerated Hoagland nutrient solution $(\mathrm{pH}=5.5-6.1)$ prepared with osmosis-generated water and $1 \mathrm{mM} \mathrm{NaCl}$ in order to reach an optimum conductivity value $\left(2.2 \mathrm{dS} \mathrm{m}^{-1}\right)$ for tomato plant and fruit development [22]. The cultivar used was Boludo, provided by Monsanto, which is an indeterminate hybrid variety for fresh consumption with a high fruit-setting capacity at high temperature and rounded fruits of medium size and homogeneous color at maturity. Thirteen days after transplanting (DAT), the temperature treatments were started, maintaining one of the greenhouses (greenhouse 1) at a maximum of $25{ }^{\circ} \mathrm{C}$ during the day, while in the other (greenhouse 2), the maximum temperature was gradually increased over three days to reach a final maximum temperature of $35^{\circ} \mathrm{C}$ during the day. These temperatures were reached naturally (without any heat source). To avoid exceeding these temperatures, the greenhouses were fitted with a control system that included shade nets, zenithal windows and a cooling system (Munters, Madrid, Spain). The shade nets were activated simultaneously in both greenhouses for twelve hours per day starting at 8 a.m. In addition, zenithal windows were opened from 6 a.m. until the temperature exceeded a temperature value of $20^{\circ} \mathrm{C}$. 
Thereafter, the maximum temperature set in each greenhouse was maintained using the cooling system. Night temperatures ranged between 20 and $13{ }^{\circ} \mathrm{C}$ throughout the growing period in a similar way in both greenhouses. The saline treatment $(60 \mathrm{mM} \mathrm{NaCl})$ was started (16 DAT) in half of the containers in each greenhouse, through the application of $20 \mathrm{mM} \mathrm{NaCl}$ for three consecutive days in order to avoid osmotic shock. The salinity level $\left(60 \mathrm{mM} \mathrm{NaCl}, 7.8 \mathrm{dS} \mathrm{m}^{-1}\right)$ was selected on the basis of previous results, which showed that this level increased tomato fruit quality and reduced yield without drastically affecting plant development [22,23]. These combinations provided a total of four treatments: control $\left(\mathrm{C}, 25^{\circ} \mathrm{C}+1 \mathrm{mM} \mathrm{NaCl}\right)$, saline $\left(\mathrm{S}, 25^{\circ} \mathrm{C}+60 \mathrm{mM} \mathrm{NaCl}\right)$, heat $\left(\mathrm{H}, 35^{\circ} \mathrm{C}+1 \mathrm{mM} \mathrm{NaCl}\right)$ and heat + salinity $\left(\mathrm{S}+\mathrm{H}, 35^{\circ} \mathrm{C}+60 \mathrm{mM} \mathrm{NaCl}\right)$, distributed in a completely randomized design with 6 replications (plants) per treatment (Figure 1). The nutrient solutions were analyzed every week, and nutrients were added when they were $10 \%$ below the starting level. The $\mathrm{pH}$ was adjusted every two days and water was added twice a week to replace that lost by evapotranspiration.

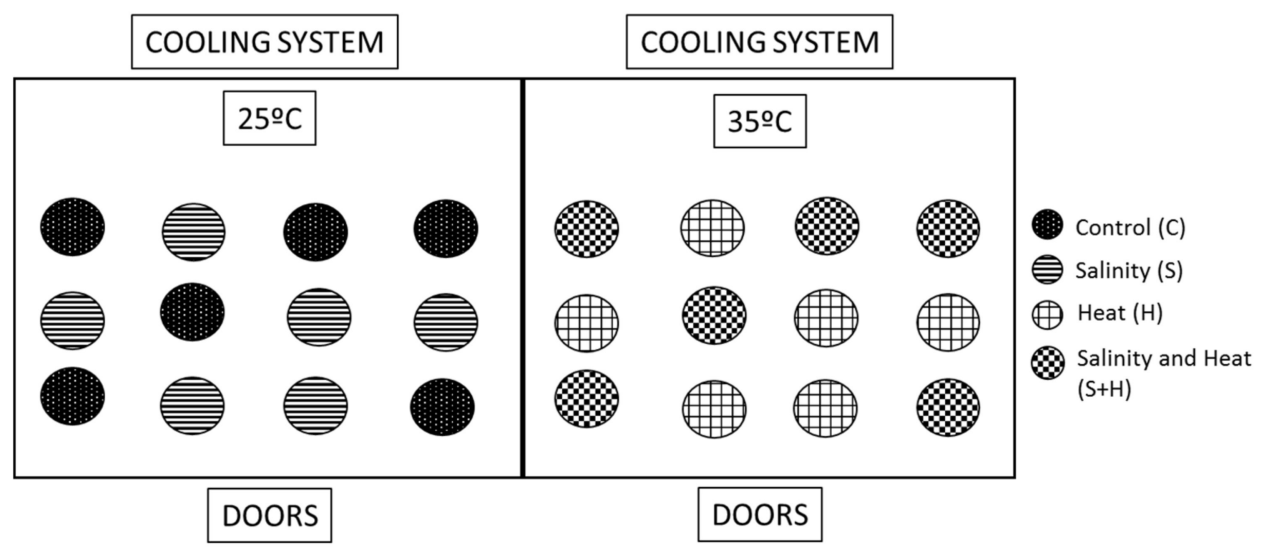

Figure 1. Experimental design layout of the greenhouse container experiment using a completely randomized design (CRD) with four treatments, control $(\mathrm{C})$, saline $(\mathrm{S})$ and heat conditions $(\mathrm{H})$ and the combination of salinity and heat $(\mathrm{S}+\mathrm{H})$, and six replicates per treatment.

Plants were allowed to grow until they produced the ninth cluster, at which point the experiment terminated. Each tomato fruit was individually weighted to determine total and commercial production and mean fruit weight. Fruits under $70 \mathrm{~g}$ and/or affected by BER or cracking were classified as non-commercial. In order to analyze tomato quality, fruits at the full-red stage of ripening from trusses two and three were sampled during the period between 157 and 164 DAT. Fruit firmness of tomatoes with intact skin was determined with a texturometer (TA XT plus Texture Analyzer, Stable Micro System, Godalming, UK). Color was determined using a Minolta colorimeter CR200 model (Minolta Company, Limited, Ramsey, NJ, USA), taking three measurements for each fruit along the equatorial axis. Tomatoes taken from the same plant were cut into small pieces and mixed, constituting a sample (six samples per treatment). Later, the fruits were homogenized, and half of the homogenate was centrifuged to determine total soluble solids (TSS), $\mathrm{pH}$ and total acidity. The other half was kept at $-80^{\circ} \mathrm{C}$ for subsequent analysis of sugars, organic acids, vitamin $\mathrm{C}$, phenolic compounds and carotenoids. Each sample was analyzed in triplicate.

Primary metabolites (soluble sugars and organic acids) and bioactive compounds (vitamin C, carotenoids and phenolic compound) were analyzed by high-performance liquid chromatography (HPLC) using a refraction index (IR) for sugars, a triple quadrupole mass spectrometer detector (MS/MS) for organic acids, vitamin $C$ and phenolic compounds and a photodiode array UV-visible detector for carotenoids, following the methodologies described by Flores et al. [24], Fenoll et al. [25] and Flores et al. [26]. The IBM SPSS Statistic 21 software was used to statistically analyze the results with a one-way ANOVA and Duncan's test. 


\section{Results and Discussion}

\subsection{Yield Parameters}

The total tomato yield obtained under control conditions was significantly reduced by the three different treatments $(p<0.001)$. The effect of salinity and heat individually was similar, and the combination of both stresses resulted in the highest yield reduction (Figure 2A). The reduction in commercial yield was even higher with all different treatments, which indicates a reduction in the percentage of commercial fruits (Figure 2B). Commercial yield was reduced from $91.8 \%$ under control conditions to $80.5,73.5$ and $65.4 \%$ with salinity, heat stress and the combination of both stresses, respectively. The above decrease in tomato yield with the different treatments was attributed to the significant reduction $(p<0.001)$ in fruit weight (Figure $2 \mathrm{C}$ ) and not to a reduction in fruit number (Figure 2D). Several authors have described a reduction in tomato fruit size but no or little effect on fruit number under saline conditions [27-30]. In regard to the decrease in fruit weight under saline conditions, this effect has been attributed to a lower water uptake by the root, thus reducing water transport to the fruit [31-33]. Unlike salinity, heat stress may affect fruit set with negative consequences for the yield [34]. However, under our experimental conditions, heat stress alone or combined with salinity had no significant effect on fruit number.

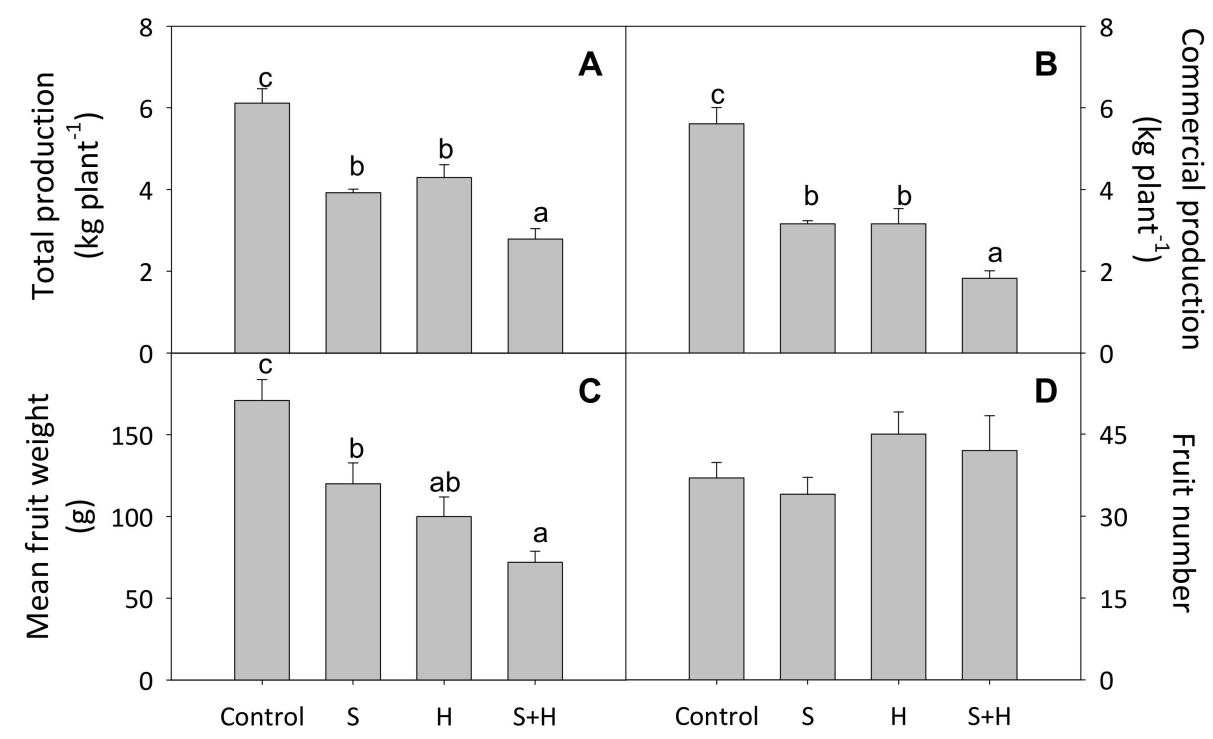

Figure 2. Total production (A), commercial production (B), fruit mean weight (C) and fruit number per plant (D) of tomato plants under control $(C)$, saline $(S)$ and heat conditions $(\mathrm{H})$ or the combination of salinity and heat $(S+H)$. Values are means $\pm S E(n=6)$. Different letters indicate significant differences between means according to Duncan's test at the 5\% level.

Different responses to combinations of stresses can be found: (1) additive, which is the addition of the single stress responses; (2) synergistic, which is the sum of each single stress; (3) idiosyncratic, when completely different from the individual stress responses; (4) dominant, if it is very close to one of the stresses [35]. Our results point to a higher negative effect of stress combinations than of each single stress on fruit yield (additive). Although Rivero et al. [9] reported that after $72 \mathrm{~h}$, the heat treatment improved the salinity tolerance of tomato plants, long-term exposure to stress, such as in the present study, would be expected to have more pronounced effects on plant physiology and fruit yield. In agreement with our results, other authors studying drought, heat and their combination in tomato plants over a period of 6 days indicated that combined stress reinforced the negative effect of the individual stresses [36]. In addition, long-term studies have indicated that different stress interactions have a higher effect on yield than any of the stresses applied individually $[8,11]$. 


\subsection{Fruit Organoleptic Properties}

Total soluble solids (TSS) significantly increased by salinity, whether applied alone or, to a lesser extent, by the combination of salinity with high temperature, while temperature alone had no effect (Table 1). The combination of both stresses significantly decreased the $\mathrm{pH}$ in fruit, and the saline treatment applied as a single stress increased acidity. Other authors have reported similar results in relation to the effect of salt stress in tomato fruits, with both soluble solids and tritable acidity increasing [37,38]. Fruit firmness decreased with the combination of salinity and heat, but there were no differences between the other treatments. None of the treatments had any effect on $\mathrm{L}$ or hue values, while chroma increased only with the combination of stresses.

Table 1. Total soluble solids (TSS, ${ }^{\circ}$ Brix), $\mathrm{pH}$, acidity ( $\mathrm{g}$ citric acid $\left.\mathrm{L}^{-1}\right)$, firmness $\left(\mathrm{N} \mathrm{cm}^{2}\right)$ and color parameters (L, hue and chroma) of tomato fruits under control $(\mathrm{C})$, saline $(\mathrm{S})$ and heat conditions $(\mathrm{H})$ or the combination of salinity and heat $(S+H)$. Values are means $(n=6)$.

\begin{tabular}{cccccccc}
\hline Treatments & TSS & $\mathbf{p H}$ & Acidity & Firmness & L & Hue & Chroma \\
\hline Control & $4.7^{\mathrm{a}}$ & $4.3^{\mathrm{bc}}$ & $2.0^{\mathrm{a}}$ & $13.8^{\mathrm{b}}$ & 42.9 & 51.6 & $39.5^{\mathrm{a}}$ \\
$\mathrm{S}$ & $5.5^{\mathrm{c}}$ & $4.2^{\mathrm{ab}}$ & $2.7^{\mathrm{b}}$ & $11.6^{\mathrm{ab}}$ & 43.9 & 54.1 & $40.7^{\mathrm{a}, \mathrm{b}}$ \\
$\mathrm{H}$ & $4.6^{\mathrm{a}}$ & $4.4^{\mathrm{c}}$ & $2.0^{\mathrm{a}}$ & $13.5^{\mathrm{ab}}$ & 43.3 & 52.6 & $39.7^{\mathrm{a}}$ \\
$\mathrm{S}+\mathrm{H}$ & $5.2^{\mathrm{b}}$ & $4.1^{\mathrm{a}}$ & $2.3^{\mathrm{a}}$ & $10.8^{\mathrm{a}}$ & 44.0 & 51.2 & $42.0^{\mathrm{b}}$ \\
& $* *$ & $* *$ & $* *$ & $*$ & n.s. & n.s. & $*$
\end{tabular}

*** Significant differences between means at the 5 or $1 \%$ level of probability, respectively; n.s., non-significant at $p=5 \%$. For each stage, different letters in the same column indicate significant differences between means according to Duncan's test at the $5 \%$ level.

The glucose and fructose contents significantly increased when salinity was applied as a single stress, but were not affected when heat was the only stress (Table 2). However, heat and salinity together had an additive effect, with the combination of both stresses resulting in the highest increase in both glucose and fructose. Many results can be found in the literature related to the increase in tomato fruit quality as a result of an increasing sugar content caused by salinity of the nutrient solution [3,27,39-41], which was attributed to the effect of saline stress on enzymes associated with sugar biosynthesis [42]. As for high temperature, no effect on the fruit's reducing sugar content has been described in tomato in spite of its impact on fruit mass production [43]. However, our findings indicated that under high temperature conditions, irrigation with saline water could increase the fruit sugar content and, therefore, lead to greater consumer preference because of the increase in sweetness and flavor.

Table 2. Concentration of soluble sugars and organic acids ( $\mathrm{mg} \mathrm{g}^{-1}$ fresh weight) in tomato fruits under control $(\mathrm{C})$, saline $(\mathrm{S})$ and heat conditions $(\mathrm{H})$ or the combination of salinity and heat $(\mathrm{S}+\mathrm{H})$. Values are means $(n=6)$.

\begin{tabular}{cccccc}
\hline Treatments & Glucose & Fructose & Citric & Glutamic & Malic \\
\hline Control & $14.75^{\mathrm{a}}$ & $15.40^{\mathrm{a}}$ & 1.59 & $3.00^{\mathrm{ab}}$ & $0.42^{\mathrm{ab}}$ \\
$\mathrm{S}$ & $20.23^{\mathrm{b}}$ & $19.80^{\mathrm{b}}$ & 1.86 & $3.41^{\mathrm{b}}$ & $0.30^{\mathrm{a}}$ \\
$\mathrm{H}$ & $13.64^{\mathrm{a}}$ & $14.32^{\mathrm{a}}$ & 1.95 & $2.23^{\mathrm{a}}$ & $0.49^{\mathrm{b}}$ \\
$\mathrm{S}+\mathrm{H}$ & $24.26^{\mathrm{c}}$ & $23.09^{\mathrm{c}}$ & 1.74 & $2.89^{\mathrm{ab}}$ & $0.41^{\mathrm{ab}}$ \\
& $* * *$ & $* * *$ & n.s. & $*$ & $*$
\end{tabular}

**** Significant differences between means at 5 or $0.1 \%$ level of probability, respectively; n.s., non-significant at $p=5 \%$. For each stage, different letters in the same column indicate significant differences between means according to Duncan's test at the $5 \%$ level.

Glutamic acid concentration was not affected by any treatment with regard to the control (Table 2), although significant differences were found between single stress applications $(p<0.05)$, being 1.5 times higher under saline than under heat stress. In the case of malic acid, the heat treatment led to a 1.6 times higher content than that obtained in 
saline conditions. Neither a single stress nor the combination of both significantly changed the citric acid concentration. Other authors have indicated that salinity increases organic acid as well as the sugar concentration $[27,44]$, but this effect was closely dependent on the tomato variety [27]. The increased concentrations of both sugars and organic acids in tomato fruits by salinity and high temperature have been previously associated to a concentration effect as a result of a decreased sink/source ratio due to increased flower abortion $[27,28]$. However, the experimental conditions in the present study did not led to a decrease in the number of fruits as a consequence of any single stress or their combination. Therefore, the increased concentrations of sugars and organic acids could be attributed to an enhanced biosynthesis under these stress conditions.

\subsection{Phenolic Compounds}

The most abundant phenolic compound was homovanillic acid-O-hexoside, with an average concentration of $26.4 \mu \mathrm{g} \mathrm{g}^{-1}$, followed by the flavonol derivative rutin $\left(10.6 \mu \mathrm{g} \mathrm{g}^{-1}\right)$ and kaempferol-3-O-rutinoside $\left(8.6 \mu \mathrm{g} \mathrm{g}^{-1}\right)$ and the flavanone naringenin $\left(7.0 \mu \mathrm{g} \mathrm{g}^{-1}\right)$. Hydroxycinnamic acids were mainly represented by chlorogenic acid $\left(5.9 \mu \mathrm{g} \mathrm{g}^{-1}\right)$. The dihydrochalcone phloretin-C-diglycoside was found at an average concentration of $3.8 \mu \mathrm{g} \mathrm{g}^{-1}$. Other detected phenolic compounds were the flavonol derivatives rutin-O-hexoside $\left(0.20 \mathrm{\mu g} \mathrm{g}^{-1}\right)$, rutin-O-pentoside $\left(0.07 \mu \mathrm{g} \mathrm{g}^{-1}\right)$, quercetin $\left(0.04 \mu \mathrm{g} \mathrm{g}^{-1}\right)$, the flavanone naringenin-O-hexoside $\left(3.1 \mu \mathrm{g} \mathrm{g}^{-1}\right)$ and the hydroxycinnamic derivatives caffeic-acid-O-hexoside $\left(2.4 \mu \mathrm{g} \mathrm{g}^{-1}\right)$, cryptochlorogenic acid $\left(1.4 \mu \mathrm{g} \mathrm{g}^{-1}\right)$, ferulic acid-O-hexoside $\left(1.3 \mu \mathrm{g} \mathrm{g}^{-1}\right)$ and $p$-coumaroyl quinic acid $\left(0.19 \mu \mathrm{g} \mathrm{g}^{-1}\right)$, dicaffeoylquinic $\left(0.15 \mu \mathrm{g} \mathrm{g}^{-1}\right)$, ferulic $\left(0.14 \mu \mathrm{g} \mathrm{g}^{-1}\right)$, caffeic $\left(0.12 \mu \mathrm{g} \mathrm{g}^{-1}\right)$ and $p$-coumaric acids $\left(0.03 \mu \mathrm{g} \mathrm{g}^{-1}\right)$. Table $\mathrm{S} 1$ shows the values of each individual phenolic compound in the different treatments.

The content of hydroxycinnamic acids was significantly reduced by the high temperature, while the other treatments had no effect on these compounds (Figure 3A). Interestingly, salinity inhibited the detrimental effect of heat on this parameter. Flavanones were not affected by salinity but decreased significantly and in a similar manner with high temperature and the combination of salinity and heat (Figure 3B), which indicates that heat dominated the combined stress response. In contrast, flavonols were significantly increased by salinity and the combination of both stresses, and no significant differences were found between both conditions, indicating the dominant effect of salinity on this parameter. No effects of heat as a single stress were observed on the flavonol content (Figure 3C). Homovanillic acid-O-hexoside was significantly higher with both stresses applied together (Figure 4A), and phloretin was significantly reduced with the saline treatment (Figure 4B).

Phenolic compounds are important for the detoxification of free radicals [45] and environmental stress can increase the levels of these scavenger molecules [21]. Regarding salinity, contradictory reports of the effects on phenolic compounds in tomato fruits can be found in the literature, increasing [46,47], decreasing [48] or even remaining unchanged [49]. The same is true of flavonoids, with some authors finding an increase in the total flavonoid content of tomato fruits under saline conditions [48] and others reporting a reduction [50]. In the case of heat stress, some authors have pointed to an increase in specific phenolic compounds [6,51] under high temperature conditions. Martínez et al. [12] described a differential accumulation of phenolic compounds that was dependent on the type of abiotic stress, concluding that the accumulation of flavonols over hydroxycinnamic acids favored oxidative damage protection under abiotic stress. In agreement with these authors, our results indicated an increase in flavonols/hydroxycinnamic acids ratio under all stress conditions, with the highest values obtained when both stresses were combined.

The different results found in the literature could be due to the influence of several factors, such as stage of ripeness and tissue, growth conditions, genotype or the detection method $[52,53]$. Our results showed the specific effects of individual and combined stresses on each phenolic compound family, which may be underestimated when the total contents are analyzed with non-selective methods. Moreover, the effect of salinity on phenolic compounds may be influenced by other factors, as mentioned by Incerti et al. [54], who re- 
ported that their level decreased or increased, depending on the season (spring or autumn). These findings highlight the need to study the interaction between different factors that are expected to coexist when evaluating the impact of abiotic stress on fruit composition.

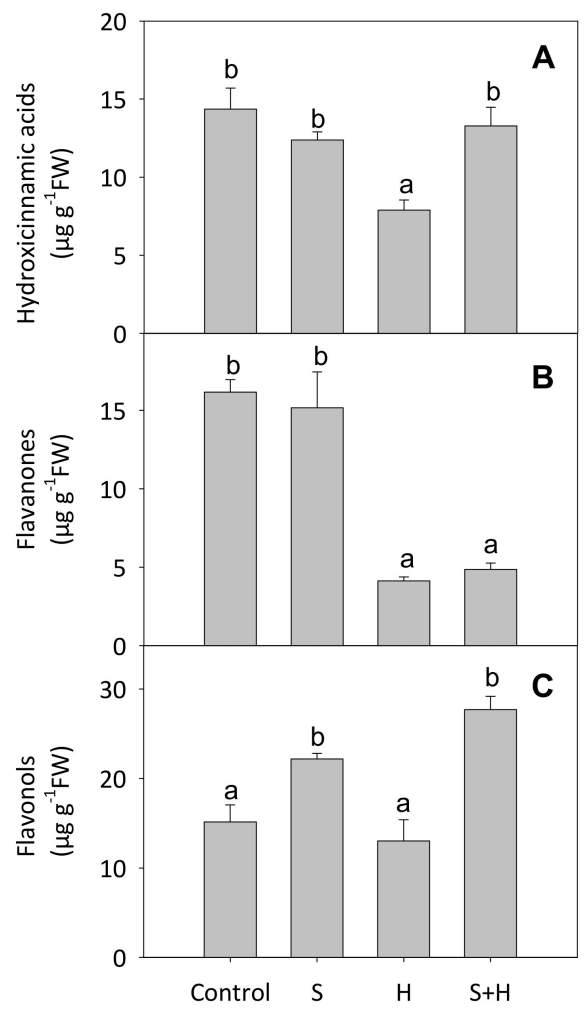

Figure 3. Concentration of hydroxycinnamic acids (A) flavanones (B) and flavonols (C) ( $\mu \mathrm{g} \mathrm{g}^{-1}$ fresh weight) in tomato fruits under control (C), saline (S) and heat conditions $(\mathrm{H})$ or the combination of salinity and heat $(\mathrm{S}+\mathrm{H})$. Values are means $\pm \mathrm{SE}(n=6)$. Different letters indicate significant differences between means according to Duncan's test at the $5 \%$ level.

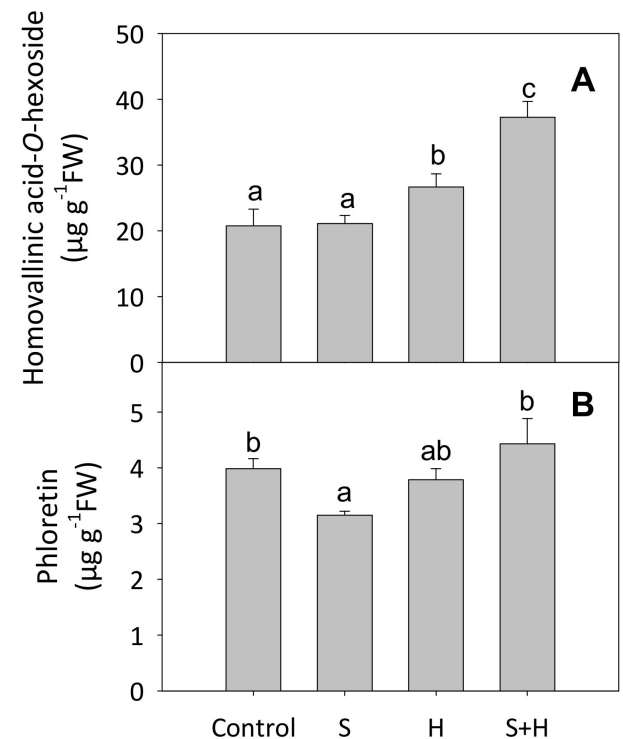

Figure 4. Concentration of homovanillic acid-O-hexoside (A) and phloretin (B) $\left(\mu \mathrm{g} \mathrm{g}^{-1}\right.$ fresh weight) in tomato fruits under control (C), saline (S) and heat conditions $(\mathrm{H})$ or the combination of salinity and heat $(\mathrm{S}+\mathrm{H})$. Values are means $\pm \mathrm{SE}(n=6)$. Different letters indicate significant differences between means according to Duncan's test at the $5 \%$ level. 


\subsection{Vitamin C}

Vitamin C concentrations increased $(p<0.01)$ similarly with high temperature and when both stresses were applied, indicating the dominant effect of heat stress and no effect of salinity (Figure 5). Gautier et al. [6] found that ascorbate levels decreased when temperature increased to $32{ }^{\circ} \mathrm{C}$, and Rosales et al. [50] observed an increase in ascorbic acid under stress conditions due to high temperature. After an initial fall, an increase in vitamin C was found by Hernández et al. [55] after a long exposure to high temperatures, suggesting that plant metabolism adapted to a high temperature and/or when the temperature decreased during the night, a restoration of the ascorbate synthesis took place. Ehret et al. [30] suggested that vitamin C concentration increased as a response to abiotic stress through de novo synthesis or due to its regeneration from dihydrolipoic acid. In spite of the increase in vitamin C caused by salinity in tomato fruits reported by other authors $[27,30,46,56]$, our results found that salinity had no effect when applied alone and no synergistic effect when applied at the same time as a high temperature.

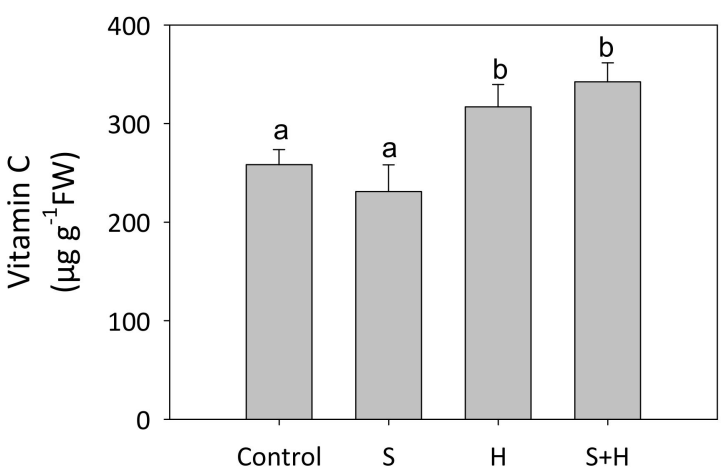

Figure 5. Concentration of vitamin $\mathrm{C}\left(\mu \mathrm{g} \mathrm{g}^{-1}\right.$ fresh weight) in tomato fruits under control (C), saline $(\mathrm{S})$ and heat conditions $(\mathrm{H})$ or the combination of salinity and heat $(\mathrm{S}+\mathrm{H})$. Values are means $\pm \mathrm{SE}$ $(n=6)$. Different letters indicate significant differences between means according to Duncan's test at the $5 \%$ level.

\subsection{Carotenoids}

Salinity applied as a single stress did not significantly affect any of the precursors or carotenoids (Figures 6 and 7). High temperature did not increase carotenoids concentrations while the concentration of phytoene (Figure 6A), phytofluene (Figure 6B) and violaxanthin (Figure 7D) decreased with heat, whether applied as a single stress or combined with salinity. In spite of what occurred with the individual stresses, lycopene and lutein increased as a response to the combination of both stresses (Figure 7A,C). As for $\beta$-carotene, no significant differences were observed between any of the single stress treatments or their combination and the control treatment (Figure 7B).

Carotenoids can contribute to the fluidity and permeability of membranes in response to changes in temperature $[57,58]$. Although heat stress $\left(32{ }^{\circ} \mathrm{C}\right)$ caused a decrease in lycopene levels, under certain conditions the fruits could recover or even increase the initial concentrations [55]. High temperature seems to have no effect on $\beta$-carotene and lutein $[6,55]$. However, some authors have reported a beneficial effect of salinity on the carotenoid content, [27,30,40,59], while Serio et al. [60] reported that salinity did not affect the lycopene content, in agreement with our results. Comparative studies have indicated that the response of carotenoids in tomato to salinity was genotype dependent [50,59].

Unlike the response to salinity or high temperature when applied separately, a specific and different response to the combination of both stresses was the increase in lycopene and lutein concentrations. Under such stress conditions, our results suggested a degradation of the precursors phytoene and phytofluene towards the accumulation of lycopene and lutein and the maintenance of $\beta$-carotene levels at the expense of a decreased accumulation of violaxanthin. These results of increased lycopene and lutein concentrations are especially 
important, considering the role of these metabolites in human health [61] and with lycopene being the principal carotenoid, which confers the red pigmentation to the fruit.

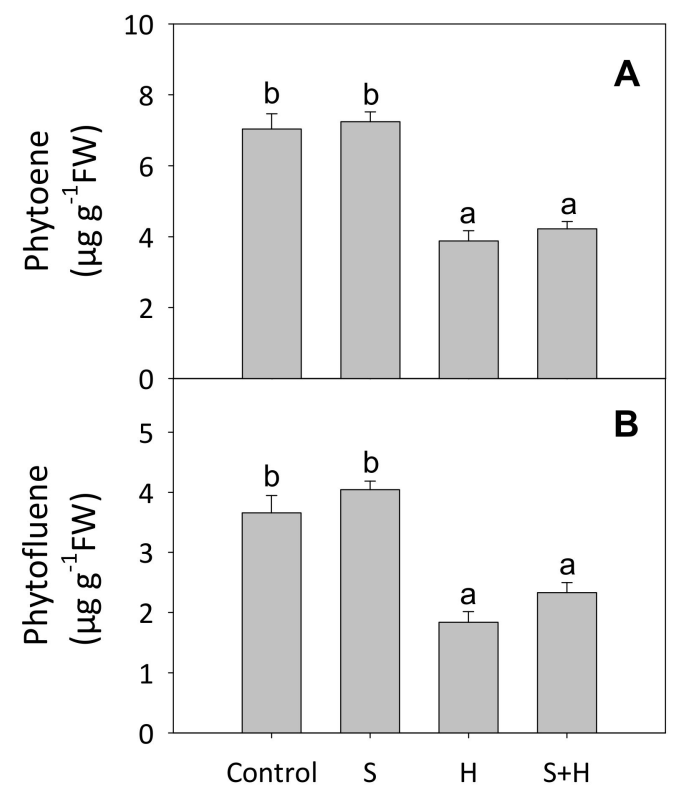

Figure 6. Concentration of phytoene (A) and phytofluene (B) $\left(\mu \mathrm{g} \mathrm{g}^{-1}\right.$ fresh weight) in tomato fruits under control $(C)$, saline $(S)$ and heat conditions $(H)$ or the combination of salinity and heat $(S+H)$. Values are means \pm SE $(n=6)$. Different letters indicate significant differences between means according to Duncan's test at the $5 \%$ level.

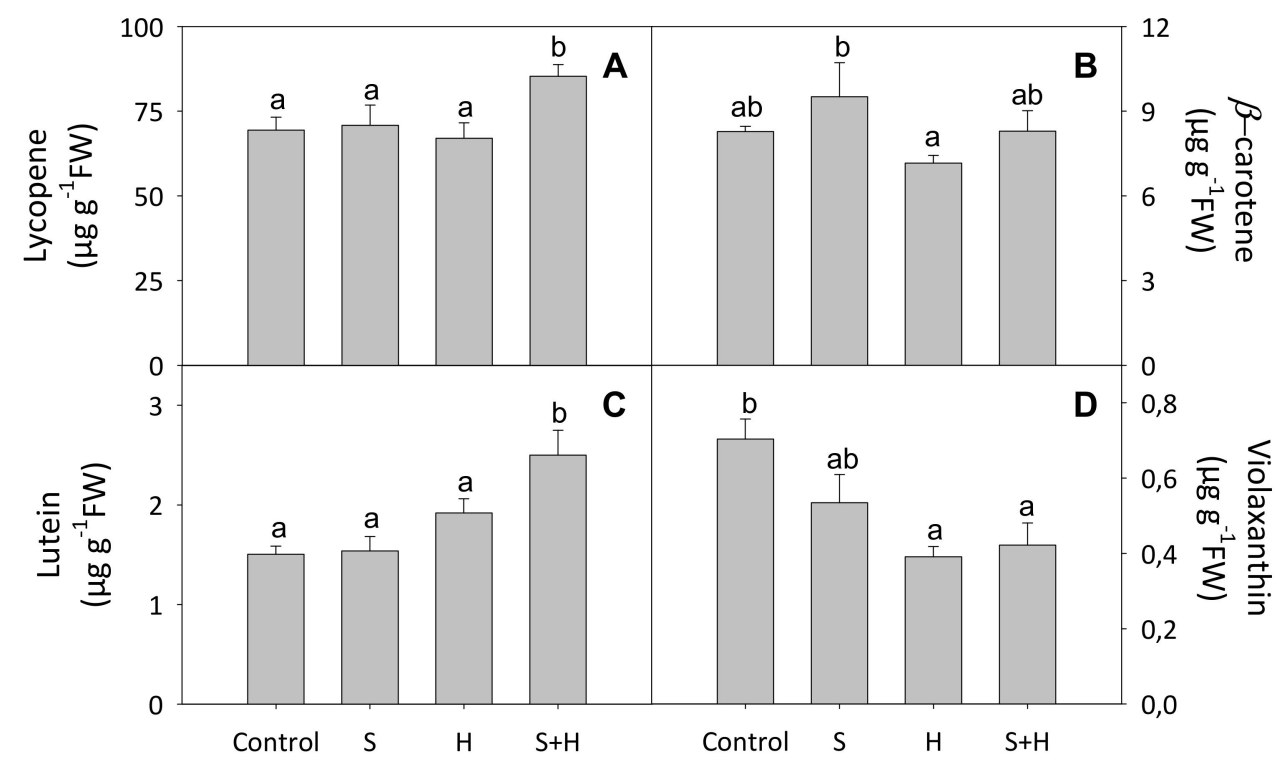

Figure 7. Concentration of lycopene (A), $\beta$-carotene (B), lutein (C) and violaxanthin (D) $\left(\mu \mathrm{g} \mathrm{g}^{-1}\right.$ fresh weight) in tomato fruits under control (C), saline (S) and heat conditions $(\mathrm{H})$ or the combination of salinity and heat $(\mathrm{S}+\mathrm{H})$. Values are means $\pm \mathrm{SE}(n=6)$. Different letters indicate significant differences between means according to Duncan's test at the $5 \%$ level.

The effect of a combination of stresses may differ from those of single stresses, highlighting the importance of studying the effect of stress interactions on the yield and quality of crops. To summarize our findings, salinity applied as a single stress decreased the yield of tomato but had a positive effect on fruit quality by increasing sugars and flavonols. High temperatures increased the vitamin $C$ content, but had a negative effect on yield and the 
content of various phenolic compounds (hydroxycinnamic acids and flavanones) and some carotenoids. Interestingly, an idiosyncrasy was found in the effect of the combination of stresses on the contents of homovallinic acid $O$-hexoside, lycopene and lutein. In addition, the combination of stresses inhibited the detrimental effect of high temperature on hydroxycinnamic acid content. The results from this preliminary study point to the viability of exploiting abiotic stresses and their combination to obtain tomatoes with increased levels of health-promoting compounds. However, it is to be expected that environmental, crop management and even varietal factors may affect the results obtained. Therefore, further studies are needed considering these factors and other abiotic stresses. Moreover, since abiotic stress combinations due to climate change are expected to severely restrict crop yield and fruit quality in the coming years, more studies that combine good crop management with new breeding tools and gene editing technologies will be needed in order to improve plant resilience and cope with the food, fiber and livestock feed demand.

Supplementary Materials: The following are available online at https://www.mdpi.com/article/10 .3390 /agriculture11060534/s1, Table S1: Concentration of individual phenolic compounds ( $\mu \mathrm{g} \mathrm{g}^{-1}$ fresh weight) in tomato fruits under control, salinity, heat or the combination of salinity and heat. Values are means $\pm \mathrm{SE}(n=6)$. Different letters indicate significant differences between means according to Duncan's test at the 5\% level.

Author Contributions: Conceptualization, P.F., V.M., R.M.R. and P.H.; methodology, V.H., T.M., P.H. and P.F.; software V.H., T.M. and M.F.G.-L.; validation V.M., P.H., M.Á.B. and P.F.; formal analysis, V.H., T.M. and M.F.G.-L.; investigation, V.H., M.Á.B., V.M., P.H. and P.F.; resources, V.M., R.M.R., P.H. and P.F.; data curation, V.H., M.Á.B. and M.F.G.-L.; writing-original draft preparation, M.Á.B. and P.F.; writing-review and editing, M.Á.B., P.F. and V.H.; visualization, M.Á.B., P.H. and J.F.; project administration, V.M. and P.F.; funding acquisition, P.F., P.H., J.F. and V.M. All authors have read and agreed to the published version of the manuscript.

Funding: This research was funded by Fundación Séneca-Agencia de Ciencia y Tecnología de la Región de Murcia.

Institutional Review Board Statement: Not applicable.

Informed Consent Statement: Not applicable.

Data Availability Statement: Data are available upon reasonable request from the authors.

Acknowledgments: The authors are grateful to Inmaculada Garrido González, María V. Molina Menor, Elia Molina Menor and Juana Cava Artero for technical assistance.

Conflicts of Interest: The authors declare no conflict of interest. The funders had no role in the design of the study; in the collection, analyses or interpretation of data; in the writing of the manuscript or in the decision to publish the results.

\section{References}

1. Botella, M.Á.; Del Amor, F.; Amorós, A.; Serrano, M.; Martinez, V.; Cerdá, A. Polyamine, ethylene and other physico-chemical parameters in tomato (Lycopersicon esculentum) fruits as affected by salinity. Physiol. Plant. 2000, 109, 428-434. [CrossRef]

2. Petersen, K.K.; Willumsen, J.; Kaack, K. Composition and taste of tomatoes as affected by increased salinity and different salinity sources. J. Hortic. Sci. Biotechnol. 1998, 73, 205-215. [CrossRef]

3. Restuccia, G.; Marchese, M.; Mauromicale, G.; Restuccia, A.; Battaglia, M. Yield and Fruit Quality of Tomato Grown in Greenhouse with Saline Irrigation Water. Acta Hortic. 2003, 614, 699-704. [CrossRef]

4. Adams, S.R.; Cockshull, K.E.; Cave, C.R.J. Effect of Temperature on the Growth and Development of Tomato Fruits. Ann. Bot. 2001, 88, 869-877. [CrossRef]

5. Islam, M.T. Effect of Temperature on Photosynthesis, Yield Attributes and Yield of Tomato Genotypes. J. Exp. Agric. Int. 2011, 2, $8-11$.

6. Gautier, H.; Diakou-Verdin, V.; Bénard, C.; Reich, M.; Buret, M.; Bourgaud, F.; Poëssel, J.L.; Caris-Veyrat, C.; Génard, M. How Does Tomato Quality (Sugar, Acid, and Nutritional Quality) Vary with Ripening Stage, Temperature, and Irradiance? J. Agric. Food Chem. 2008, 56, 1241-1250. [CrossRef]

7. Arena, C.; Conti, S.; Francesca, S.; Melchionna, G.; Hájek, J.; Barták, M.; Barone, A.; Rigano, M.M. Eco-Physiological Screening of Different Tomato Genotypes in Response to High Temperatures: A Combined Field-to-Laboratory Approach. Plants 2020, 9, 508. [CrossRef] 
8. Mittler, R.; Blumwald, E. Genetic Engineering for Modern Agriculture: Challenges and Perspectives. Annu. Rev. Plant Biol. 2010, 61, 443-462. [CrossRef]

9. Rivero, R.M.; Mestre, T.C.; Mittler, R.; Rubio, F.; Garcia-Sanchez, F.; Martinez, V. The combined effect of salinity and heat reveals a specific physiological, biochemical and molecular response in tomato plants. Plant Cell Environ. 2013, 37, 1059-1073. [CrossRef] [PubMed]

10. Zandalinas, S.I.; Mittler, R.; Balfagón, D.; Arbona, V.; Gómez-Cadenas, A. Plant adaptations to the combination of drought and high temperatures. Physiol. Plant. 2018, 162, 2-12. [CrossRef] [PubMed]

11. Suzuki, N.; Rivero, R.M.; Shulaev, V.; Blumwald, E.; Mittler, R. Abiotic and biotic stress combinations. New Phytol. 2014, 203, 32-43. [CrossRef] [PubMed]

12. Martinez, V.; Mestre, T.C.; Rubio, F.; Girones-Vilaplana, A.; Moreno, D.A.; Mittler, R.; Rivero, R.M. Accumulation of Flavonols over Hydroxycinnamic Acids Favors Oxidative Damage Protection under Abiotic Stress. Front. Plant Sci. 2016, 7, 838. [CrossRef] [PubMed]

13. García-Martí, M.; Piñero, M.C.; García-Sanchez, F.; Mestre, T.C.; López-Delacalle, M.; Martínez, V.; Rivero, R.M. Amelioration of the Oxidative Stress Generated by Simple or Combined Abiotic Stress through the $\mathrm{K}^{+}$and Ca2+ Supplementation in Tomato Plants. Antioxidants 2019, 8, 81. [CrossRef] [PubMed]

14. Scarano, A.; Olivieri, F.; Gerardi, C.; Liso, M.; Chiesa, M.; Chieppa, M.; Frusciante, L.; Barone, A.; Santino, A.; Rigano, M.M. Selection of tomato landraces with high fruit yield and nutritional quality under elevated temperatures. J. Sci. Food Agric. 2020, 100, 2791-2799. [CrossRef] [PubMed]

15. Tan, H.-L.; Thomas-Ahner, J.M.; Grainger, E.M.; Wan, L.; Francis, D.M.; Schwartz, S.J.; Erdman, J.W.; Clinton, S.K. Tomato-based food products for prostate cancer prevention: What have we learned? Cancer Metastasis Rev. 2010, 29, 553-568. [CrossRef]

16. Sommerburg, O.; Keunen, J.E.; Bird, A.C.; Van Kuijk, F.J.G.M. Fruits and vegetables that are sources for lutein and zeaxanthin: The macular pigment in human eyes. Br. J. Ophthalmol. 1998, 82, 907-910. [CrossRef] [PubMed]

17. Giorio, G.; Yildirim, A.; Stigliani, A.L.; D'Ambrosio, C. Elevation of lutein content in tomato: A biochemical tug-of-war between lycopene cyclases. Metab. Eng. 2013, 20, 167-176. [CrossRef]

18. Riso, P.; Visioli, F.; Grande, S.; Guarnieri, S.; Gardana, C.; Simonetti, P.; Porrini, M. Effect of a Tomato-Based Drink on Markers of Inflammation, Immunomodulation, and Oxidative Stress. J. Agric. Food Chem. 2006, 54, 2563-2566. [CrossRef]

19. Slimestad, R.; Verheul, M. Review of flavonoids and other phenolics from fruits of different tomato (Lycopersicon esculentum Mill.) cultivars. J. Sci. Food Agric. 2009, 89, 1255-1270. [CrossRef]

20. Dumas, Y.; Dadomo, M.; Di Lucca, G.; Grolier, P. Effects of environmental factors and agricultural techniques on antioxidantcontent of tomatoes. J. Sci. Food Agric. 2003, 83, 369-382. [CrossRef]

21. Toscano, S.; Trivellini, A.; Cocetta, G.; Bulgari, R.; Francini, A.; Romano, D.; Ferrante, A. Effect of Preharvest Abiotic Stresses on the Accumulation of Bioactive Compounds in Horticultural Produce. Front. Plant Sci. 2019, 10, 1212. [CrossRef]

22. Dorai, M.; Papadopoulos, A.P. Influence of electric conductivity management on greenhouse tomato yield and fruit quality. Agronomy 2001, 21, 367-383. [CrossRef]

23. Navarro, J.M.; Flores, P.; Carvajal, M.; Martinez, V. Changes in quality and yield of tomato fruit with ammonium, bicarbonate and calcium fertilisation under saline conditions. J. Hortic. Sci. Biotechnol. 2005, 80, 351-357. [CrossRef]

24. Flores, P.; Hellín, P.; Fenoll, J. Determination of organic acids in fruits and vegetables by liquid chromatography with tandem-mass spectrometry. Food Chem. 2012, 132, 1049-1054. [CrossRef]

25. Fenoll, J.; Martínez, A.; Hellín, P.; Flores, P. Simultaneous determination of ascorbic and dehydroascorbic acids in vegetables and fruits by liquid chromatography with tandem-mass spectrometry. Food Chem. 2011, 127, 340-344. [CrossRef]

26. Flores, P.; Hernández, V.; Hellín, P.; Fenoll, J.; Cava, J.; Mestre, T.; Martinez, V. Metabolite profile of the tomato dwarf cultivar Micro-Tom and comparative response to saline and nutritional stresses with regard to a commercial cultivar. J. Sci. Food Agric. 2015, 96, 1562-1570. [CrossRef] [PubMed]

27. Magán, J.; Gallardo, M.; Thompson, R.; Lorenzo, P. Effects of salinity on fruit yield and quality of tomato grown in soil-less culture in greenhouses in Mediterranean climatic conditions. Agric. Water Manag. 2008, 95, 1041-1055. [CrossRef]

28. Li, Y.L.; Stanghellini, C.; Challa, H. Effect of electrical conductivity and transpiration on production of greenhouse tomato (Lycopersicon esculentum L.). Sci. Hortic. 2001, 88, 11-29. [CrossRef]

29. Eltez, R.; Tüzel, Y.; Gül, A.; Tuzel, I.; Duyar, H. Effects of different EC levels of nutrient solution on greenhouse tomato growing. Acta Hortic. 2002, 573, 443-448. [CrossRef]

30. Ehret, D.L.; Usher, K.; Helmer, T.; Block, G.; Steinke, D.; Frey, B.; Kuang, T.; Diarra, M. Tomato Fruit Antioxidants in Relation to Salinity and Greenhouse Climate. J. Agric. Food Chem. 2013, 61, 1138-1145. [CrossRef]

31. Mitchell, J.P.; Shennan, C.; Grattan, S.R. Developmental changes in tomato fruit composition in response to water deficit and salinity. Physiol. Plant. 1991, 83, 177-185. [CrossRef]

32. Mitchell, J.; Shennan, C.; Grattan, S.; May, D. Tomato Fruit Yields and Quality under Water Deficit and Salinity. J. Am. Soc. Hortic. Sci. 1991, 116, 215-221. [CrossRef]

33. Sakamoto, Y.; Watanabe, S.; Nakashima, T.; Okano, K. Effects of salinity at two ripening stages on the fruit quality of single-truss tomato grown in hydroponics. J. Hortic. Sci. Biotechnol. 1999, 74, 690-693. [CrossRef]

34. Gonzalo, M.J.; Li, Y.-C.; Chen, K.-Y.; Gil, D.; Montoro, T.; Nájera, I.; Baixauli, C.; Granell, A.; Monforte, A.J. Genetic Control of Reproductive Traits in Tomatoes Under High Temperature. Front. Plant Sci. 2020, 11, 326. [CrossRef] [PubMed] 
35. Prasch, C.M.; Sonnewald, U. Signaling events in plants: Stress factors in combination change the picture. Environ. Exp. Bot. 2015, 114, 4-14. [CrossRef]

36. Zhou, R.; Kong, L.; Wu, Z.; Rosenqvist, E.; Wang, Y.; Zhao, L.; Zhao, T.; Ottosen, C.-O. Physiological response of tomatoes at drought, heat and their combination followed by recovery. Physiol. Plant. 2018, 165, 144-154. [CrossRef] [PubMed]

37. Balibrea, M.E.; Cuartero, J.; Bolarín, M.C.; Pérez-Alfocea, F. Sucrolytic activities during fruit development of Lycopersicon genotypes differing in tolerance to salinity. Physiol. Plant. 2003, 118, 38-46. [CrossRef] [PubMed]

38. Zushi, K.; Matsuzoe, N. Metabolic profile of organoleptic and health-promoting qualities in two tomato cultivars subjected to salt stress and their interactions using correlation network analysis. Sci. Hortic. 2015, 184, 8-17. [CrossRef]

39. Flores, P.; Navarro, J.M.; Carvajal, M.; Cerdá, A.; Martinez, V. Tomato yield and quality as affected by nitrogen source and salinity. Agronomy 2003, 23, 249-256. [CrossRef]

40. Fanasca, S.; Martino, A.; Heuvelink, E.; Stanghellini, C. Effect of electrical conductivity, fruit pruning, and truss position on quality in greenhouse tomato fruit. J. Hortic. Sci. Biotechnol. 2007, 82, 488-494. [CrossRef]

41. Zhang, P.; Senge, M.; Dai, Y. Effects of Salinity Stress on Growth, Yield, Fruit Quality and Water Use Efficiency of Tomato Under Hydroponics System. Rev. Agric. Sci. 2016, 4, 46-55. [CrossRef]

42. Saito, T.; Fukuda, N.; Matsukura, C.; Nishimura, S. Effects of Salinity on Distribution of Photosynthates and Carbohydrate Metabolism in Tomato Grown using Nutrient Film Technique. J. Jpn. Soc. Hortic. Sci. 2009, 78, 90-96. [CrossRef]

43. Kläring, H.-P.; Klopotek, Y.; Krumbein, A.; Schwarz, D. The effect of reducing the heating set point on the photosynthesis, growth, yield and fruit quality in greenhouse tomato production. Agric. For. Meteorol. 2015, 214-215, 178-188. [CrossRef]

44. Zhang, P.; Senge, M.; Yoshiyama, K.; Ito, K.; Dai, Y.; Zhang, F. Effects of Low Salinity Stress on Growth, Yield and Water Use Efficiency of Tomato Under Soilless Cultivation. IDRE J. 2017, 85, 15-21. [CrossRef]

45. Ksouri, R.; Megdiche, W.; Debez, A.; Falleh, H.; Grignon, C.; Abdelly, C. Salinity effects on polyphenol content and antioxidant activities in leaves of the halophyte Cakile maritima. Plant Physiol. Biochem. 2007, 45, 244-249. [CrossRef] [PubMed]

46. Sgherri, C.; Navari-Izzo, F.; Pardossi, A.; Soressi, G.P.; Izzo, R. The Influence of Diluted Seawater and Ripening Stage on the Content of Antioxidants in Fruits of Different Tomato Genotypes. J. Agric. Food Chem. 2007, 55, 2452-2458. [CrossRef]

47. Krauss, S.; Schnitzler, W.H.; Grassmann, A.J.; Woitke, M. The Influence of Different Electrical Conductivity Values in a Simplified Recirculating Soilless System on Inner and Outer Fruit Quality Characteristics of Tomato. J. Agric. Food Chem. 2006, 54, 441-448. [CrossRef]

48. Hernández-Fuentes, A.D.; López-Vargas, E.R.; Pinedo-Espinoza, J.M.; Campos-Montiel, R.G.; Valdés-Reyna, J.; Juárez-Maldonado, A. Postharvest Behavior of Bioactive Compounds in Tomato Fruits Treated with Cu Nanoparticles and NaCl Stress. Appl. Sci. 2017, 7, 980. [CrossRef]

49. Kim, H.-J.; Fonseca, J.M.; Kubota, C.; Kroggel, M.; Choi, J.-H. Quality of fresh-cut tomatoes as affected by salt content in irrigation water and post-processing ultraviolet-C treatment. J. Sci. Food Agric. 2008, 88, 1969-1974. [CrossRef]

50. Moles, T.M.; Francisco, R.D.B.; Mariotti, L.; Pompeiano, A.; Lupini, A.; Incrocci, L.; Carmassi, G.; Scartazza, A.; Pistelli, L.; Guglielminetti, L.; et al. Salinity in Autumn-Winter Season and Fruit Quality of Tomato Landraces. Front. Plant Sci. 2019, 10, 1078. [CrossRef]

51. Rosales, M.A.; Cervilla, L.M.; Sánchez-Rodríguez, E.; Rubio-Wilhelmi, M.D.M.; Blasco, B.; Rios, J.J.; Soriano, T.; Castilla, N.; Romero, L.; Ruiz, J.M. The effect of environmental conditions on nutritional quality of cherry tomato fruits: Evaluation of two experimental Mediterranean greenhouses. J. Sci. Food Agric. 2010, 91, 152-162. [CrossRef] [PubMed]

52. Slimestad, R.; Verheul, M.J. Seasonal Variations in the Level of Plant Constituents in Greenhouse Production of Cherry Tomatoes. J. Agric. Food Chem. 2005, 53, 3114-3119. [CrossRef] [PubMed]

53. Slimestad, R.; Fossen, T.; Verheul, M.J. The Flavonoids of Tomatoes. J. Agric. Food Chem. 2008, 56, 2436-2441. [CrossRef]

54. Incerti, A.; Navari-Izzo, F.; Pardossi, A.; Izzo, R. Seasonal variations in polyphenols and lipoic acid in fruits of tomato irrigated with sea water. J. Sci. Food Agric. 2009, 89, 1326-1331. [CrossRef]

55. Hernández, V.; Hellín, P.; Fenoll, J.; Flores, P. Increased Temperature Produces Changes in the Bioactive Composition of Tomato, Depending on Its Developmental Stage. J. Agric. Food Chem. 2015, 63, 2378-2382. [CrossRef]

56. Zushi, K.; Matsuzoe, N. Effect of Soil Water Deficit on Vitamin C, Sugar, Organic Acid, Amino Acid and Carotene Contents of Large-fruited Tomatoes. J. Jpn. Soc. Hortic. Sci. 1998, 67, 927-933. [CrossRef]

57. Nisar, N.; Li, L.; Lu, S.; Khin, N.C.; Pogson, B.J. Carotenoid Metabolism in Plants. Mol. Plant 2015, 8, 68-82. [CrossRef] [PubMed]

58. Spicher, L.; Glauser, G.; Kessler, F. Lipid Antioxidant and Galactolipid Remodeling under Temperature Stress in Tomato Plants. Front. Plant Sci. 2016, 7, 167. [CrossRef] [PubMed]

59. Borghesi, E.; González-Miret, M.L.; Escudero-Gilete, M.L.; Malorgio, F.; Heredia, F.J.; Melendez-Martinez, A.J. Effects of Salinity Stress on Carotenoids, Anthocyanins, and Color of Diverse Tomato Genotypes. J. Agric. Food Chem. 2011, 59, 11676-11682. [CrossRef] [PubMed]

60. Serio, F.; De Gara, L.; Caretto, S.; Leo, L.; Santamaria, P. Influence of an increased NaCl concentration on yield and quality of cherry tomato grown in Posidonia (Posidonia oceanica (L.) Delile). J. Sci. Food Agric. 2004, 84, 1885-1890. [CrossRef]

61. Przybylska, S. Lycopene-A bioactive carotenoid offering multiple health benefits: A review. Int. J. Food Sci. Technol. 2020, 55, 11-32. [CrossRef] 